\title{
Serangan Sitophilus oryzae Pada Beras Dari Beberapa Varietas Padi dan Suhu Penyimpanan
}

\section{Sitophilus oryzae Attack on Rice from Several Paddy Varieties and Storage Temperature}

\author{
Rizma Dwi Mastuti*, Subagiya, Retno Wijayanti \\ Department of Agrotechnology, Faculty of Agriculture, Universitas Sebelas Maret, Surakarta, Indonesia \\ ${ }^{*}$ Corresponding author: dwi.rizma.rd@gmail.com
}

Received: September 24, 2019; Accepted: March 15, 2020; Published: April 1, 2020

\begin{abstract}
Post-harvest with storage are important to maintain the supply of rice. One of the obstacles found in storing rice is the attack of Sitophilus oryzae which is responsible of causing yield loss. The attack of S. oryzae on rice can be caused by storage temperature and protein content on rice. The objective of this research was to determine the attack rate of S.oryzae in several paddy varieties and different storage temperatures. The research was conducted in Laboratory of Pest and Plant Disease Faculty of Agriculture Universitas Sebelas Maret from March-June 2019. The method used was Nested Design with 2 factors and 3 replications. The treatments given were storage temperature $\left(29^{\circ} \mathrm{C}, 39^{\circ} \mathrm{C}, 49^{\circ} \mathrm{C}\right.$ and $59^{\circ} \mathrm{C}$ ) and paddy varieties (brown rice, black rice, Rojolele and IR64). Observation variable were number of imago, pupae, larvae, percentage of decrease in rice weight, broken rice and rice powder. The results showed that $S$. oryzae was able to survive at a storage temperature of $29^{\circ} \mathrm{C}$. Storage temperatures which increased by more than $29^{\circ} \mathrm{C}$ causing mortality of S.oryzae up to $100 \%$. The longer storage time will cause an increase in population and S.oryzae attack rate. Key words: mortality, protein content, rice weight
\end{abstract}

Cite this as: Mastuti, R. D., Subagiya, \& Wijayanti, R. (2020). Serangan Sitophilus oryzae Pada Beras Dari Beberapa Varietas Padi dan Suhu Penyimpanan. Agrosains : Jurnal Penelitian Agronomi 22(1): 16-20. DOI: http://dx.doi.org/10.20961/agsjpa.v22i1.34672

\section{PENDAHULUAN}

Beras adalah salah satu jenis bahan pangan pokok penting di Indonesia. Berdasarkan data yang dihimpun Badan Pusat Statistik (2016), pada tahun 2015 beras menempati urutan pertama sebagai bahan pangan pokok dengan jumlah produksi terbesar di Indonesia, yaitu mencapai 75.397.841 ton atau $62,3 \%$ dari total produksi bahan pangan pokok di Indonesia. Jumlah produksi beras yang besar perlu adanya upaya pasca panen yang tepat guna mempertahankan pasokan beras tetap tersedia untuk mencukupi kebutuhan pangan nasional. Tahapan pasca panen beras yang penting dilakukan salah satunya adalah penyimpanan. Dalam penyimpanan beras sering ditemui adanya kendala, salah satunya adalah serangan hama beras Sitophilus oryzae.

Menurut Hendrival dan Muetia (2016), kehilangan hasil yang disebabkan serangan $S$. oryzae pada beras dapat mencapai lebih dari $24 \%$ dan terus meningkat saat beras semakin lama disimpan. Serangan S. oryzae pada beras dapat dipengaruhi oleh faktor eksternal dan internal. Salah satu faktor ekternal yang berpengaruh terhadap serangan $S$. oryzae adalah suhu penyimpanan, sedangkan salah satu faktor internal yang berpengaruh adalah kandungan protein pada beras.
Khare dan Agrawal (1970) menjelaskan bahwa suhu yang cenderung rendah $\left(13-18^{\circ} \mathrm{C}\right)$ menyebabkan mortalitas yang tinggi pada hama, sedangkan suhu yang cenderung hangat $\left(25-30^{\circ} \mathrm{C}\right)$ menyebabkan oviposisi dan tingkat bertahan hidup dari hama menjadi lebih tinggi. Susrama (2017) menjelaskan bahwa konsentrasi protein dapat berpengaruh terhadap tingkat oviposisi $S$. oryzae. Hubungan antara tingkat serangan $S$. oryzae terhadap suhu penyimpanan dan kandungan protein pada beberapa varietas padi perlu diketahui. Tujuan penelitian ini adalah untuk mengetahui tingkat serangan S. oryzae pada beberapa varietas padi dan suhu penyimpanan berbeda.

\section{BAHAN DAN METODE}

Penelitian ini dilaksanakan di Laboratorium Hama dan Penyakit Tumbuhan Fakultas Pertanian, Universitas Sebelas Maret, Surakarta pada bulan Maret-Juni 2019. Penelitian ini dilakukan dengan menggunakan Rancangan Tersarang dengan 2 faktor perlakuan, yaitu suhu penyimpanan dan varietas padi. Suhu penyimpanan yang digunakan adalah $29^{\circ} \mathrm{C}, 39^{\circ} \mathrm{C}, 49^{\circ} \mathrm{C}$, dan $59^{\circ} \mathrm{C}$, sedangkan varietas padi yang digunakan adalah beras merah, beras hitam, beras Rojolele, dan beras IR64. Setiap 
kombinasi perlakuan diulang sebanyak 3 kali, sehingga terdapat 48 unit percobaan.

Alat yang digunakan meliputi mikroskop stereo, stoples plastik, kain, karet, kuas, pinset, incubator chamber, timbangan analitik, saringan dan nampan. Bahan yang digunakan dalam penelitian ini berupa beras merah, beras hitam, beras Rojolele, dan beras IR64 dengan berat 100 gram untuk setiap unit percobaan.

Penelitian diawali dengan perbanyakan S. oryzae dari koloni imago yang berumur seragam hingga didapatkan imago F1. Langkah selanjutnya adalah menginfestasikan 5 pasang imago $\mathrm{F} 1$ pada sebanyak $100 \mathrm{~g}$ beras 100\% utuh dari varietas padi berbeda dan dimasukkan ke dalam stoples plastik. Beras yang telah diinfestasikan dengan imago $S$. oryzae lantas disimpan berdasarkan perlakuan suhu simpan selama 60 hari.

Variabel yang diamati adalah jumlah imago, jumlah pupa, jumlah larva, persentase kehilangan bobot beras, persentase beras pecah, dan persentase bubuk beras. Pengamatan dilakukan setiap interval 10 hari selama 60 hari penyimpanan. Data yang diperoleh dianalisis dengan menggunakan analisis ragam (Anova) pada taraf kepercayaan 95\%, apabila berpengaruh nyata dilakukan uji lanjut dengan menggunakan DMRT (Duncan Mutiple Range Test). Data yang diperoleh juga dianalisis menggunakan analisis regresi.

\section{HASIL DAN PEMBAHASAN}

\section{Gejala serangan S. oryzae}

Gejala serangan S. oryzae mulai terlihat pada hari kesepuluh setelah infestasi dan semua varietas padi menunjukkan gejala serangan awal yang sama (Gambar 1). Gejala serangan S. oryzae pada bulir beras dimulai dengan terbentuknya beberapa lubang tak beraturan bekas gigitan pada bagian permukaan bulir beras. Davidson dan Lyon (1979) menjelaskan bahwa lubang kecil pada bulir beras dibuat oleh serangga betina dengan alat mulutnya sebelum melakukan oviposisi telur pada bulir beras. Bulir beras yang terserang apabila dibuka akan menunjukkan tanda serangan berupa keberadaan $S$. oryzae pada stadia larva dan pupa.

Serangan lanjut akan menyebabkan bagian dalam bulir beras berubah menjadi bubuk dan menyisakan bagian pericarp. Kumar (2017) menjelaskan bahwa serangan $S$. oryzae dapat menyebabkan kerusakan parah pada bulir dan hanya akan menyisakan pericarp bulir, sementara sisa massa dari bulir beras akan habis dimakan. Kerusakan beras dari dalam bulir disebabkan oleh aktivitas makan larva yang berada di dalam bulir beras terserang. Menurut Davidson dan Lyon (1979), seluruh fase perkembangan larva dan pupa terjadi di dalam bulir beras.

Serangan pada bulir beras putih varietas IR64 dan Rojolele menunjukkan gejala yang lebih jelas dan mudah dibedakan dengan bulir beras yang tidak terserang. Gejala ini berupa terdapatnya alur berwarna putih susu pada bulir yang berwarna putih bening. Alur ini lama kelamaan akan semakin besar dan mengubah warna keseluruhan bulir beras dari putih bening menjadi putih susu. Booroto et al. (2017) menjelaskan bahwa gejala putih mengapur disertai dengan keberadaan alur putih tak beraturan pada bulir beras disebabkan oleh aktivitas gerekan larva $S$. oryzae yang berada didalam bulir beras. Gejala serangan $S$. oryzae pada varietas padi merah dan hitam dapat dilihat dari keberadaan lubang di permukaan bulir beras terserang.

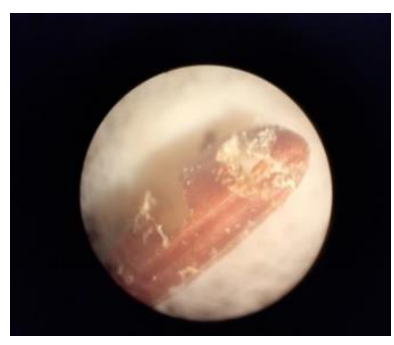

(A)

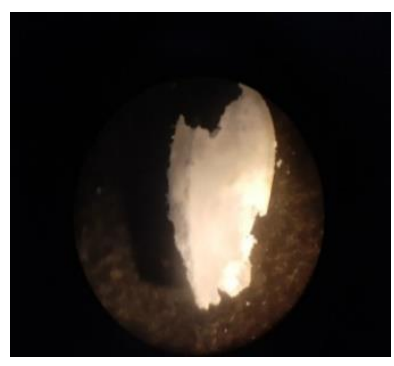

(C)

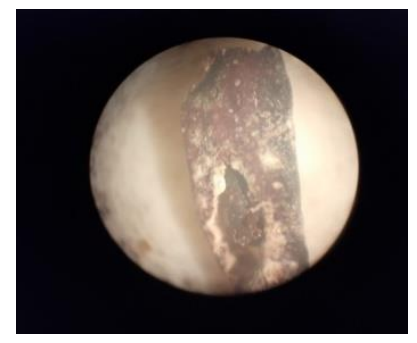

(B)

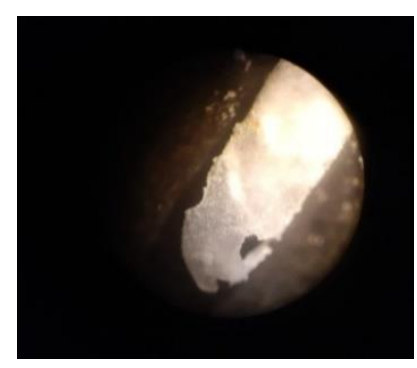

(D)
Gambar 1. Gejala serangan pada beras merah (A), beras hitam (B), beras Rojolele (C), dan beras IR64 (D) (skala 1:15)

\section{Populasi Sitophilus oryzae}

Perlakuan varietas tidak berpengaruh nyata terhadap rata-rata jumlah populasi (Tabel 1). Perlakuan suhu penyimpanan dapat mempengaruhi populasi $S$. oryzae. Total populasi $S$. oryzae pada suhu $2^{\circ} \mathrm{C}$ adalah 41,75 ekor. Perlakuan suhu yang semakin tinggi dapat menurunkan jumlah populasi S. oryzae (Tabel 2). Rees (2004) melaporkan bahwa S. oryzae dapat berkembang dengan baik pada kisaran suhu $15-34^{\circ} \mathrm{C}$. Menurut Vijay dan Bhuvaneswari (2017) kisaran suhu yang paling menguntungkan untuk kelangsungan hidup $S$. oryzae adalah 30,5-35,25ㄷ. Menurut Birch (1945) suhu yang paling optimal untuk perkembangan $S$. oryzae adalah $29,1^{\circ} \mathrm{C}$. Menurut El-Aw et al. (2016) perkembangan $S$. oryzae akan mencapai puncaknya pada $25-28^{\circ} \mathrm{C}$ dan kelembaban udara/RH $65-73 \%$.

Rata-rata populasi pada suhu penyimpanan $39^{\circ} \mathrm{C}$, $49^{\circ} \mathrm{C}$ dan $59^{\circ} \mathrm{C}$ adalah 0 (Tabel 2). Hal ini karena seluruh imago $S$. oryzae yang diinfestasi pada ketiga suhu mengalami mortalitas sejak pengamatan hari ke-1, sehingga hama tidak mengalami perkembangbiakan. Mortalitas imago $S$. oryzae disebabkan karena suhu penyimpanan yang terlalu tinggi tidak mendukung $S$. oryzae untuk berkembang. Menurut Yasin (2009) suhu adalah salah satu faktor iklim yang dapat mempengaruhi siklus hidup Sitophilus spp dari fase telur hingga dewasa. 
Tabel 1. Pengaruh varietas padi terhadap tingkat serangan S. oryzae

\begin{tabular}{ccccc}
\hline \multirow{2}{*}{ Varietas padi } & \multicolumn{4}{c}{ Serangan S. oryzae } \\
\cline { 2 - 5 } & $\begin{array}{c}\text { Populasi } \\
\text { (ekor) }\end{array}$ & $\begin{array}{c}\text { Kehilangan bobot } \\
(\%)\end{array}$ & $\begin{array}{c}\text { Beras pecah } \\
(\%)\end{array}$ & $\begin{array}{c}\text { Bubuk Beras } \\
(\%)\end{array}$ \\
\hline Merah & 8,25 & 0,76 & 2,28 & 0,23 \\
Hitam & 15,34 & 0,82 & 3,61 & 0,36 \\
Rojolele & 13,04 & 0,89 & 2,90 & 0,46 \\
IR64 & 5,09 & 1,40 & 2,33 & 0,10 \\
\hline
\end{tabular}

Ket: Angka dengan huruf yang sama pada kolom yang sama menunjukkan arti yang tidak berbeda nyata berdasarkan DMRT pada taraf $5 \%$

Tabel 2. Pengaruh suhu penyimpanan terhadap tingkat serangan S. oryzae

\begin{tabular}{ccccc}
\hline $\begin{array}{c}\text { Suhu } \\
\text { penyimpanan }\left({ }^{\circ} \mathrm{C}\right)\end{array}$ & \multicolumn{4}{c}{ Serangan S. oryzae } \\
\cline { 2 - 5 } & $\begin{array}{c}\text { Populasi } \\
\text { (ekor) }\end{array}$ & $\begin{array}{c}\text { Kehilangan bobot } \\
(\%)\end{array}$ & $\begin{array}{c}\text { Beras pecah } \\
(\%)\end{array}$ & $\begin{array}{c}\text { Bubuk Beras } \\
(\%)\end{array}$ \\
\hline 29 & $41,75 \mathrm{a}$ & $3,86 \mathrm{a}$ & $11,12 \mathrm{a}$ & $1,14 \mathrm{a}$ \\
39 & $0,00 \mathrm{~b}$ & $0,00 \mathrm{~b}$ & $0,00 \mathrm{~b}$ & $0,00 \mathrm{~b}$ \\
49 & $0,00 \mathrm{~b}$ & $0,00 \mathrm{~b}$ & $0,00 \mathrm{~b}$ & $0,00 \mathrm{~b}$ \\
59 & $0,00 \mathrm{~b}$ & $0,00 \mathrm{~b}$ & $0,00 \mathrm{~b}$ & $0,00 \mathrm{~b}$ \\
\hline
\end{tabular}

Ket: Angka dengan huruf yang sama pada kolom yang sama menunjukkan arti yang tidak berbeda nyata berdasarkan uji Duncan pada taraf $5 \%$

Suhu yang optimal untuk perkembangan S. oryzae adalah $29^{\circ} \mathrm{C}$ atau suhu kamar rata-rata. Suhu yang dinaikkan menyebabkan mortalitas S. oryzae. Menurut Shazali dan Smith (1985), S. oryzae yang diinkubasi pada suhu $35^{\circ} \mathrm{C}$ akan mengalami mortalitas pada hari ke-10 setelah infestasi. S. oryzae yang diinkubasi pada suhu $35^{\circ} \mathrm{C}$ memiliki perilaku yang tidak tenang, aktivitas makan menurun dan tingkat mortalitas yang tinggi. Sebaliknya, hasil penelitian Hasan et al. (2017) menunjukkan bahwa $S$. oryzae yang diinfestasikan pada suhu $25^{\circ} \mathrm{C}$ memiliki perkembangan yang lambat, sedangkan $S$. oryzae yang diinfestasikan pada suhu $35^{\circ} \mathrm{C}$ menunjukkan tingkat perkembangan yang tinggi pada semua tahap perkembangan.

Total populasi S. oryzae yang diinfestasikan pada beras mengalami peningkatan selama 60 hari pada suhu penyimpanan $29^{\circ} \mathrm{C}$. Hal ini terjadi karena imago S. oryzae yang diinfestasikan di awal penyimpanan mengalami perkembangbiakan, sehingga total populasi dari $S$. oryzae mengalami peningkatan. Hal ini sesuai dengan pendapat Hendrival dan Meutia (2016) bahwa populasi S. oryzae yang diinfestasikan pada berasakan mengalami peningkatan saat beras semakin lama disimpan. Periode penyimpanan yang lama dapat memberikan cukup waktu untuk $S$. oryzae berkembang biak secara luas, sehingga populasi dari hama dapat mengalami peningkatan.

S. oryzae dalam fase larva dan pupa mulai muncul pada hari ke-30 setelah infestasi. Menurut Choudhury dan Chakraborty (2014), periode inkubasi telur S. oryzae akan berlangsung selama 6-7 hari di dalam bulir beras. Telur kemudian menetas menjadi larva dengan total periode selama 22-29 hari. Larva selanjutnya akan berubah menjadi pupa yang periodenya akan terjadi selama 7-8 hari, sebelum akhirnya akan berubah menjadi imago. Hasil penelitian Singh (2017) menunjukkan bahwa seluruh fase metamorfosis $S$. oryzae dapat terjadi selama 42 hari pada lingkungan laboratorium. Menurut hasil penelitian Okram dan Hath (2019), S. oryzae jantan dan betina memiliki total sikus hidup yang berbeda. Siklus hidup $S$. oryzae jantan berlangsung selama 62,64-96,09 hari, dan siklus hidup $S$. oryzae betina berlangsung selama 84,33 hingga 114,61 hari.

\section{Karakteristik kehilangan bobot beras}

Perlakuan varietas tidak berpengaruh nyata terhadap persentase kehilangan bobot beras dan persentase beras pecah akibat serangan $S$. oryzae (Tabel 1). Perlakuan suhu penyimpanan memberikan pengaruh nyata terhadap persentase kehilangan bobot beras dan persentase beras pecah akibat serangan $S$. oryzae (Tabel 2). Pada suhu penyimpanan $29^{\circ} \mathrm{C}$, rata-rata kehilangan bobot beras adalah $3,86 \%$, sedangkan rata-rata beras pecah yang terbentuk adalah $11,12 \%$.

Perlakuan suhu yang lebih tinggi dapat menurunkan jumlah kehilangan hasil akibat serangan $\mathrm{S}$. oryzae. Rata-rata kehilangan bobot beras dan beras pecah pada suhu penyimpanan $39^{\circ} \mathrm{C}, 49^{\circ} \mathrm{C}$, dan $59^{\circ} \mathrm{C}$ adalah $0 \%$ (Tabel 2). Hal ini karena keseluruhan imago $S$. oryzae yang diinfestasikan pada ketiga suhu telah mengalami kematian pada awal pengamatan. Menurut Shazali dan Smith (1985) suhu $\geq 35^{\circ} \mathrm{C}$ merupakan suhu yang berada di atas kisaran toleransi $S$. oryzae untuk bertahan hidup.

Selama penyimpanan suhu $29^{\circ} \mathrm{C}$, terjadi pertambahan persentase kehilangan bobot beras dan beras pecah pada semua varietas padi. Hal ini disebabkan karena waktu penyimpanan yang semakin lama akan menyebabkan peningkatan populasi hama S. oryzae. Booroto et al. (2017) menjelaskan bahwa semakin lama disimpan, persentase kehilangan bobot beras dan beras pecah akan meningkat karena terjadi peningkatan jumlah populasi dan aktivitas makan $S$. oryzae yang diinfestasikan. Hal ini juga sesuai dengan pendapat Singh et al. (2013) bahwa kepadatan populasi hama memiliki hubungan yang erat dengan tingkat 
kehilangan berat beras yang ditimbulkan. Lebih lanjut Harinta (2016) menjelaskan bahwa populasi S. oryzae yang semakin padat dapat meningkatkan terjadinya kehilangan bobot beras.

\section{Persentase bubuk beras}

Persentase bubuk beras dihitung pada saat akhir pengamatan yaitu 60 hari setelah infestasi. Perlakuan varietas tidak mempengaruhi persentase bubuk beras (Tabel 1). Perlakuan suhu penyimpanan memberikan pengaruh terhadap persentase bubuk beras (Tabel 2).

Rata-rata bubuk beras yang terbentuk pada suhu $29{ }^{\circ} \mathrm{C}$ adalah $1,14 \%$. Perlakuan suhu yang semakin tinggi dapat menurunkan jumlah persentase bubuk beras akibat serangan $S$. oryzae. Hendrival dan Melinda (2017) menjelaskan bahwa bubuk beras terbentuk dari aktivitas makan hama primer beras S.oryzae selama di penyimpanan. Aktivitas makan ini akan menyebabkan bulir beras menjadi rapuh sehingga mudah hancur menjadi bubuk. Kerusakan bulir beras hingga membentuk bubuk selama di penyimpanan akan menyebabkan beras menjadi tidak layak konsumsi.

Persentase bubuk beras yang terbentuk pada berbagai varietas padi akan berbeda. Perbedaan persentase bubuk beras yang terbentuk pada berbagai varietas padi ini terjadi karena perbedaan ciri fisik serta kandungan nutrisi dalam masingmasing varietas, sehingga menyebabkan perbedaan tingkat serangan oleh $S$. oryzae. Soujanya et al. (2016) menjelaskan bahwa serangan hama S. oryzae pada produk pasca panen dapat dipengaruhi oleh ciri biofisik, struktur anatomi bahan, serta kandungan biokimia produk.

\section{Regresi kandungan protein beras terhadap populasi S. oryzae}

Kadar protein beras dan jumlah populasi memiliki hubungan positif yang tidak erat $\left(R^{2}=0,317\right)$. Jumlah populasi terendah terhadap kandungan protein beras terjadi pada rentang kandungan protein 7,26 - 8,75 \% wb (Gambar 1). Populasi akan mengalami peningkatan saat terjadi peningkatan kadar protein.

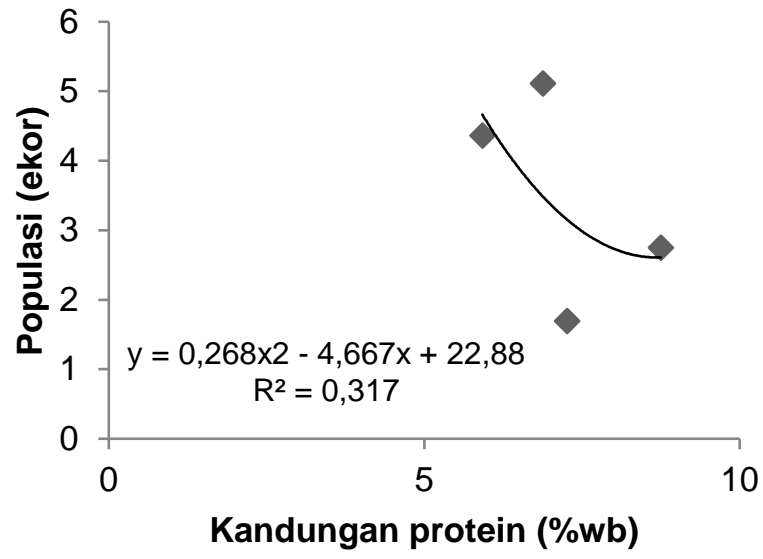

Gambar 2. Regresi kandungan protein pada varietas padi dengan populasi $S$. oryzae
Hasil penelitian Akhtar et al. (2015) menunjukkan bahwa kandungan protein dapat mempengaruhi tingkat kepadatan populasi $S$. oryzae, dimana tingkat populasi akan mencapai titik minimum pada kadar protein $8,09 \%$ dan mencapai titik maksimum pada kadar protein 9,71\%.Roriz dan Joachim-Bravo (2013) menjelaskan bahwa serangga jantan dewasa yang memperoleh banyak asupan protein akan lebih disukai oleh serangga betina dewasa, sehingga kesempatan kawin yang terjadi akan semakin banyak dan populasi serangga akan semakin tinggi pula.

\section{Regresi kandungan protein beras terhadap tingkat serangan $S$. oryzae}

Kadar protein beras dan persentase kehilangan bobot beras memiliki hubungan negatif yang tidak erat $\left(R^{2}=0,389\right)$. Persen kehilangan bobot beras mencapai titik maksimum pada kandungan protein $7,26 \%$ wb. Kehilangan hasil akan mengalami penurunan saat terjadi peningkatan kandungan protein (Gambar 3).

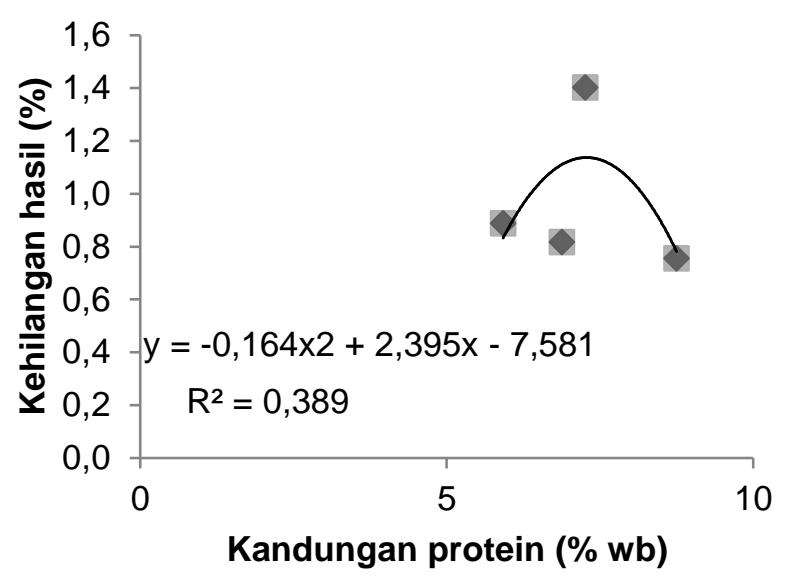

Gambar 3. Regresi kandungan protein pada varietas padi dengan persentase kehilangan bobot beras akibat serangan S. oryzae

Menurut hasil penelitian Hendrival dan Melinda (2017) bahwa salah satu hal yang dapat mempengaruhi tingkat kerusakan yang terjadi pada beras di penyimpanan adalah tingkat kepadatan populasi $S$. oryzae yang diinfestasikan. Semakin tinggi populasi hama, maka akan semakin tinggi pula tingkat kerusakan yang terjadi. Hal ini berkaitan dengan aktivitas makan S.oryzae yang dipengaruhi oleh protein beras.

\section{KESIMPULAN}

S. oryzae mampu bertahan hidup pada suhu penyimpanan $29^{\circ} \mathrm{C}$. Suhu penyimpanan yang meningkat melebihi $29{ }^{\circ} \mathrm{C}$ akan menyebabkan $S$. oryzae mengalami mortalitas mencapai $100 \%$. Varietas padi tidak berpengaruh terhadap tingkat serangan $S$. oryzae pada beras di penyimpanan.

Sebaiknya rentang suhu yang diberikan sebagai perlakuan penyimpanan dimulai dari suhu minimal di bawah suhu optimal hingga suhu maksimal di atas suhu optimal, sehingga dapat diketahui tingkat serangan hama $S$. oryzae pada rentang suhu yang lebih luas. 


\section{DAFTAR PUSTAKA}

Akhtar, M., Razza, A. B., Iram, N., Chaudry, M. I., \& Azzeem, M. (2015). Effect of infestation of Sitophilus oryzae L. (Coleoptera: Curculiontdae) on protein quality of rice under storage conditions. Int. J Agric. Appl. Sci. 7(1) : 43-45

Badan Pusat Statistik. (2016). Produksi padi nasional 1993-2015. Badan Pusat Statistik Indonesia. URL: $\quad$ https://www.bps.go.id/site/resultTab. Diakses pada 19 September 2018.

Birch, L. C. (1945). The influence of temperature on the development of the different stages of Culundra oryrae L. and Rhizopertha dominica Fab. (Coleoptera). Aust. J exp. Biol. med. Sci. 23: 29-35.

Booroto, L. A., Goo, N., \& Noya, S. H. (2017). Populasi imago Sitophilus oryzae L. (Coleoptera: Curculionidae) pada beberapa jenis beras asal Desa Waimital. Kecamatan Kairatu. J Budidaya Pertanian 13(1): 36-41.

Choudhury, S. D., \& Chakraborty, K. (2014). Study on both the life cycle and morphometrics of Sitophilus oryzae on rice cultivar Sampa mashuri in laboratory condition. Journal of Applied Science and Research 2 (6):22-28 .

Davidson, R. H., \& Lyon, W. F. (1979). Insect pests: of farm, garden, and orchard. John Wiley \& Sons, INC.Canada.

El-Aw, M. A., Askar, S. I. S., Abd El-Latif, A. M., \& Al-Asaal M. 2016. Effect of different temperatures on some biological parameters of Anisopteromalus calandrae, (Howard) (Hymenoptera: Pteromalidae) and population fluctuation of the parasitoid and their insect hosts of the genus sitophilus (Coleoptera: Curculionidae). International Journal of Entomology and Nematology Research 1(1):1-12.

Harinta, Y. W. (2016). Uji ketahanan beberapa jenis beras (Oryza sativa) terhadap hama kumbang bubuk beras (Sitophilus oryzae). J Agrovivor 9(2): 96-104.

Hasan, M., Aslam, A., Jafir, M., Javed, M. W., Shehzad, M., Chaudhary, M. Z., \& Aftab, M. (2017). Effect of temperature and relative humidity on development of Sitophilus oryzae L. (coleoptera: curculionidae). Journal of Entomology and Zoology Studies 5(6): 85-90.

Hendrival, H., \& Melinda, L. (2017). Pengaruh Kepadatan Populasi Sitophilus oryzae (L.) terhadap Pertumbuhan Populasi dan Kerusakan Beras. Biospecies, 10(1).

Hendrival, H., \& Muetia, R. (2016). Pengaruh Periode Penyimpanan Beras terhadap Pertumbuhan Populasi Sitophilus oryzae (L.) dan Kerusakan
Beras. Biogenesis: Jurnal Ilmiah Biologi, 4(2), 95-101.

Khare, B. P., \& Agrawal, N. S. (1970). Effect of temperature, relative humidity and food material on the biology of Sitophilus oryzae Linnaeus and Rhizopertha dominica Fabricius. J. Beitr. But. Bd. 20: 183-188. DOI:10.21248/contrib.entomol.20. 1-2.183-188.

Kumar, R. (2017). Insect pests of stored grain: biology, behavior, and management strategies. Apple Academic Press Inc.Oakville

Okram, S., \& Hath, T. K. (2019). Biology of Sitophilus oryzae (L.) (Coleoptera: Curculionidae) on stored rice grains during different seasons in Terai AgroEcology of West Bengal. Int. J. Curr. Microbiol. App.Sci 8(4): 1955-1963.

Rees, D. (2004). Insect of stored products. Csiro Publishing. Collingwood.

Roriz, A. K. P., \& Joachim-Bravo, I. S. (2013). The relevance of age and nutritional status on the mating competitiveness of medfly males (Diptera: Teprhitidae). Zoologia 30 (5): 506-512. DOI:10.1590/S198446702013000500006.

Shazali, M. E. H., \& Smith, R. H. (1985). Life history studies of internally feeding pests of stored sorghum: Sitotroga cerealella (L.) and Sitophilus oryzae (L.). J srored Prod. Res. 21(4): 171-178.

Singh, B. K. P. (2017). Study on the life cycle of Sitophilus oryzae on rice cultivar pusa 2-21 in laboratory condition. International Journal of Education \& Applied Sciences Research 4(2): 37-42.

Singh, P., Satya, S., \& Naik, S. N. (2013). Effect of insect infestation on quality parameters of wheat. International Conference on Food and Agricultural Sciences 55(2013): 79-82.

Soujanya, P. L., Sekhar, J. C., Karjagi, C. G., \& Paul, D. (2016). Evaluation of biophysical, anatomical and biochemical traits of resistance to Sitophilus oryzae L (Coleoptera: Curculionidae) in stored maize. Maydica61: 1-8.

Susrama, I. G. K. (2017). Kebutuhan nutrisi dan substansi dalam pakan buatan serangga. E-Jurnal Agroekoteknologi Tropika 6(3): 310-318.

Vijay, S., \& Bhuvaneswari, K. (2017). Effect of temperature on oviposition and developmentof Sitophilus oryzae L. feeding on split pulses. Journal of Entomology and Zoology Studies 5(3): 1100-1105

Yasin, M. (2009). Kemampuan akses makan serangga hama kumbang bubuk dan faktor fisikokimia yang mempengaruhinya. Prosiding Seminar Nasional Serealia 2009. Balai Penelitian Tanaman Serealia. 